\title{
Kajian Kuat Lentur Balok Beton Komposit Dengan Angkur Baja Tulangan
}

\author{
Johanna Indah Mannuela ${ }^{1}$, Novita Cahyaningtyas ${ }^{2}$ \\ email: johannajola96@gmail.com ${ }^{1}$, novitacah@outlook.com ${ }^{2}$ \\ ${ }^{1,2}$ Universitas Katolik Soegijapranata; Jl. Pawiyatan Luhur IV/1 Bendan Dhuwur Semarang \\ ${ }^{3}$ Program Studi Teknik Sipil, Fakultas Teknik, Unika Soegijapranata, Semarang
}

\begin{abstract}
Concrete is a structural element in a building that is widely known and utilized. However, in the construction world there are various problems that occur, one of the problems is on concrete beams. Well planned and designed construction always changes, failures and damage. One way of strengthening and improving the structure is with the method of composting the old concrete beams with new concrete blocks with reinforced steel anchors reinforced with chemicalanchor. This research uses a cylindrical test specimen, normal concrete beam measuring $15 \mathrm{~cm} \times 15 \mathrm{~cm}$ $\times 60 \mathrm{~cm}$, monolith concrete beam measuring $15 \mathrm{~cm} \times 30 \mathrm{~cm} \times 60 \mathrm{~cm}$, and composite concrete beam with reinforced steel anchors reinforced with chemicalanchor HILTI HIT RE-500 V3 is 15 $\mathrm{cm} \times 30 \mathrm{~cm} \times 60 \mathrm{~cm}$. The test was carried out to determine the bending strength values of the normal beam and composite beams and to know the increase of the bending strength values between normal, monolithic and composite concrete beams. The size of the maximum bending moments of concrete beams length $15 \mathrm{~cm} \times 15 \mathrm{~cm} \times 60 \mathrm{~cm}$ the biggest is $4820 \mathrm{~kg}$. For the maximum bending moments of the new concrete beam specimens measuring $15 \mathrm{~cm} \times 15 \mathrm{~cm} \times 60$ $\mathrm{cm}$ is $4110 \mathrm{~kg}$. The average value of long bending strength of old concrete beams measuring 15 $\mathrm{cm} \times 15 \mathrm{~cm} \times 60 \mathrm{~cm}$ is $53.06 \mathrm{~kg} / \mathrm{cm}^{2}$. For the average value of new flexible concrete beams measuring $15 \mathrm{~cm} \times 15 \mathrm{~cm} \times 60 \mathrm{~cm}$ is $51.91 \mathrm{~kg} / \mathrm{cm}^{2}$. The maximum bending moments of monolith concrete beam specimens measuring $15 \mathrm{~cm} \times 30 \mathrm{~cm} \times 60 \mathrm{~cm}$ is $14733.33 \mathrm{~kg}$. The average flexural strength is $49.11 \mathrm{~kg} / \mathrm{cm}^{2}$. The maximum bending moments of composite concrete beam is $15 \mathrm{~cm}$ $\times 30 \mathrm{~cm} \times 60 \mathrm{~cm}$ the largest is $13100 \mathrm{~kg}$. For the average bending strength value is $43.67 \mathrm{~kg} / \mathrm{cm}^{2}$.
\end{abstract}

Keywords: modulus of rupture, composite beam, anchor, chemichal anchor

\section{PENDAHULUAN}

Dalam perencanaan konstruksi, beton merupakan elemen struktural pada bangunan yang banyak dikenal dan dimanfaatkan. Beton juga memiliki fungsi yang sangat luas dalam suatu konstruksi bangunan. Dalam perkembangannya, beton menjadi bagian konstruksi yang banyak digunakan dalam bangunan rumah, gedung, jalan raya, jembatan, dan lain-lain. Menurut SNI 03-2847-2002, beton normal merupakan beton yang memiliki berat isi $2200 \mathrm{~kg} / \mathrm{m}^{3}-2500$ $\mathrm{kg} / \mathrm{m}^{3}$ menggunakan agregat alam yang dipecah. Dalam penggunaannya, beton memiliki kelebihan dibanding dengan bahan lain yaitu memiliki kekuatan tekan yang relatif tinggi, ketahanan terhadap api dan air, struktur yang kokoh, biaya pemeliharaan yang rendah serta bahan baku penyusun yang mudah didapat. Pada dunia konstruksi terdapat banyak permasalahan yang terjadi, salah satunya yang terjadi pada balok beton. Di Hotel Quirin yang terletak di Jalan Gajah Mada No. 44-52 Semarang pada konstruksi bangunannya akan mengganti atap genting dan digantikan oleh pelat beton. 
Dimensi balok yang sudah ada tidak cukup besar jika harus menahan beban pelat beton yang akan dibuat. Oleh karena itu dimensi balok harus diperbesar agar mampu menahan beban yang bekerja pada pelat beton tersebut. Pada permasalahan yang terjadi di Hotel Quirin pembesaran dimensi balok diatasi dengan penggunaan struktur komposit antara balok beton dengan balok beton yang sambungkan dengan baja tulangan.

Struktur komposit merupakan gabungan antara dua atau lebih bahan bangunan yang berbeda sehingga merupakan satu kesatuan dalam menahan gaya atau beban luar. Struktur komposit memanfaatkan sifat fisik dan mekanik masing-masing bahan sehingga akan diperoleh komponen yang lebih baik dan memiliki kelebihan tertentu bila dibandingkan dengan bahan yang membentuknya. Terkadang dalam pelaksanaannya, konstruksi yang telah direncanakan dan didesain sebaik mungkin selalu ada perubahan, kegagalan maupun kerusakan.

Kegagalan dan kerusakan pada struktur bangunan dapat terjadi karena adanya perubahan fungsi bangunan seperti penambahan beban kerja. Dalam kaitannya dengan mempertahankan struktur bangunan tersebut maka dapat dilakukan dengan suatu perkuatan struktur yang dilakukan berdasarkan jenis kerusakan yang terjadi. Cara ini dilakukan karena lebih efisien baik dari segi waktu dan biaya dibandingkan dengan pembangunan kembali bangunan tersebut. Oleh karena itu Hotel Quirin memilih perkuatan struktur dengan cara pengkompositan dengan pertimbangan waktu dan biaya yang akan dikeluarkan.

Metode pengkompositan yang digunakan merupakan penambahan angkur yang diperkuat dengan chemical anchor yang bertujuan untuk pengikat antara beton lama dan beton baru sehingga balok komposit tersebut merupakan satu kesatuan yang dapat bereaksi terhadap beban kerja dan juga diharapkan dapat menahan gaya lentur dengan baik.

\section{TINJAUAN PUSTAKA}

\subsection{Perkuatan Atau Retrofitting}

Retrofitting merupakan suatu kegiatan memperkuat atau memperbaiki struktur bangunan yang sudah ada agar biaya dalam perencanaan konstruksi bangunan bisa lebih menghemat biaya. Tujuan dari retrofitting adalah untuk menghasilkan perkuatan bangunan yang lebih kuat lagi dari sebelumnya. Sebelum melakukan retrofitting, ada beberapa hal yang harus diperhatikan antara lain:

1. Melakukan peninjauan ke lapangan.

2. Melakukan pemeriksaan terhadap material dan mutu bahan yang digunakan.

3. Menganalisa penyebab kerusakan bangunan.

4. Menganalisa kekuatan bangunan apakah masih mampu menahan beban atau tidak.

5. Setelah melakukan analisa, jika dianggap struktur bangunan masih mampu menahan beban maka retrofitting tidak perlu dilakukan. Dan sebaliknya, jika struktur bangunan dirasa tidak mampu menahan beban, maka perbaikan terhadap struktur yang rusak harus dilakukan, dapat berupa menambahkan material lain misalnya pemakaian wrap/fiber, penambahan struktur baja, pemasangan external prestress, dan lain sebagainya.

6. Setelah retrofitting selesai dilaksanakan di lapangan, bangunan tersebut harus dianalisa kembali untuk memastikan bahwa struktur benarbenar dalam kondisi aman.

\subsection{Beton}

Menurut SNI-03-2847-2002, pengertian beton adalah campuran antara semen portland atau semen hidraulik lainnya, agregat halus, agregat kasar, dan air, dengan atau tanpa bahan tambahan 
yang membentuk masa padat. Belakangan ini definisi dari beton sudah semakin luas, yaitu beton adalah bahan yang terbuat dari berbagai macam tipe semen, agregat dan juga bahan pozzolan, abu terbang, terak dapur tinggi, sulfur, serat dan lain-lain (Neville dan Brooks, 1987).

\subsubsection{Kelebihan dan Kekurangan Beton}

Menurut Antoni dan P. Nugraha (2007), beton memiliki beberapa faktor kelebihan dan kekurangan. Beberapa kelebihan beton antara lain:

1. Ketersediaan (availability) material dasar.

2. Kekuatan tekan tinggi.

3. Kemudahan untuk digunakan (versatility).

4. Kemampuan (adaptability).

beradaptasi

5. Kebutuhan pemeliharaan yang minimal.

Disamping segala kelebihan yang dimiliki, beton sebagai struktur juga mempunyai beberapa kelemahan yang perlu dipertimbangkan, antara lain sebagai berikut:

1. Kuat tariknya rendah, meskipun kekuatan tekannya besar.

2. Beton cenderung retak, karena semennya hidraulis.

3. Berat sendiri beton yang besar, sekitar $2400 \mathrm{~kg} / \mathrm{m}^{3}$.

4. Bentuk yang telah dibuat sulit diubah (tidak dapat bongkar pasang).

5. Kualitasnya sangat tergantung dari cara pelaksanaan di lapangan.

6. Daya pantul suara yang besar.

7. Beton tidak mampu menahan gaya tegangan (tension) yang tinggi, karena elastisitasnya yang rendah dari beton.

8. Konduktivitas termal beton relatif rendah.

\subsubsection{Beton Normal}

Yang dimaksud dengan beton normal menurut SNI 03-2847-2002 adalah beton yang mempunyai berat isi $2200-2500 \mathrm{~kg} / \mathrm{m}^{3}$ dengan agregat alam yang dipecah maupun tanpa dipecah. Beton yang banyak dijumpai dan dipakai saat ini adalah beton normal. Ditinjau dari nilai kuat tekannya, beton normal mempunyai nilai kuat tekan yang berkisar antara 20-40 MPa.

\subsubsection{Bahan Penyusun Beton}

Bahan utama pembentuk beton adalah agregat, semen, dan air. Untuk menyesuaikan beberapa sifat beton biasanya campuran beton diberikan bahan tambah (admixture). Kualitas beton yang diinginkan dapat ditentukan dari pemilihan bahan pembentuk beton yang akan digunakan, perhitungan mix design yang tepat, cara pengerjaan beton dan proses perawatan beton itu sendiri (curing). Pemilihan dan dosis bahan tambah (admixture) juga harus disesuaikan dengan perencanaan yang ada agar mutu beton yang diinginkan tercapai.

\subsubsection{Perawatan/Curing Beton}

Setelah beton jadi maka perlu dilakukan proses perawatan/curing beton. Proses ini bertujuan agar proses panas hidrasi semen dapat berjalan dengan sempurna sehingga dapat memperoleh kuat tekan beton yang diinginkan. Dalam proses hidrasi dibutuhkan kondisi dengan kelembaban tertentu, karena apabila kondisi lingkungan kering maka dapat menyebabkan keretakan pada beton. Retaknya beton dapat menurunkan kekuatan beton, sehingga dapat menyebabkan kegagalan struktur.

\subsubsection{Kuat Tekan Beton}

Kuat tekan beton adalah besarnya beban per satuan luas, yang menyebabkan benda uji beton hancur akibat gaya tertentu yang dihasilkan oleh mesin kuat tekan. Kuat tekan beton merupakan salah satu sifat yang penting dari beton dibandingkan dengan sifat yang lainnya. 
Kekuatan tekan beton ditentukan dari perencanaan campuran beton yang dapat ditentukan dari perbandingan semen, agregat, air dan bahan tambah yang digunakan.

Nilai kuat tekan beton didapatkan dengan cara pengujian standar dengan menggunakan mesin uji. Benda uji beton yang digunakan merupakan silinder dengan dimensi $15 \mathrm{~cm} \times 30 \mathrm{~cm}$. Silinder beton kemudian diberi beban bertingkat dengan kecepatan peningkatan tertentu dengan mesin kuat tekan sampai beton tersebut hancur.

Untuk mendapatkan besarnya tegangan hancur pada benda uji silinder digunakan rumus :

$$
f c^{\prime}=P / A
$$

Keterangan:

$f_{c^{\prime}}=$ Kuat tekan beton benda uji silinder (MPa)

$\mathrm{P}=$ Beban desak maksimum $(\mathrm{N})$

$\mathrm{A}=$ Luas permukaan benda uji silinder $\left(\mathrm{mm}^{2}\right)$

Ilustrasi pengujian kuat tekan beton dapat dilihat pada Gambar 1.

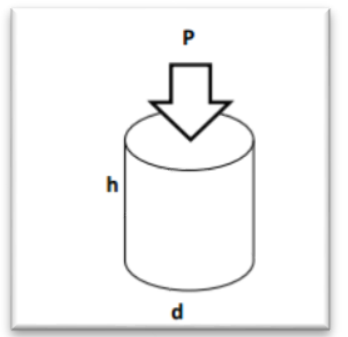

Gambar 1. Ilustrasi Pengujian Kuat

Tekan (Sumber: Google, 2018)

\subsubsection{Kuat Lentur Beton}

Kuat lentur balok beton adalah kemampuan balok beton yang diletakan pada dua perletakan untuk menahan gaya dengan arah tegak lurus sumbu benda uji yang diberikan padanya, sampai benda uji patah dan dinyatakan dalam Mega Pascal (MPa) gaya tiap satuan luas (SNI-44311997).
Rumus perhitungan kuat lentur menurut SNI-4431-2011 adalah sebagai berikut:

1. Untuk pengujian dengan keadaan bidang patah terletak di daerah pusat (daerah 1/3 jarak titik perletakan bagian tengah), maka kuat lentur beton dihitung menurut persamaan sebagai berikut.

$$
\sigma=\frac{P \times L}{b \times h^{2}}
$$

Ilustrasi yang lebih jelas mengenai gambar patah pada daerah pusat atau $1 / 3$ jarak titik perletakan bagian tengah dapat dilihat pada Gambar 2.

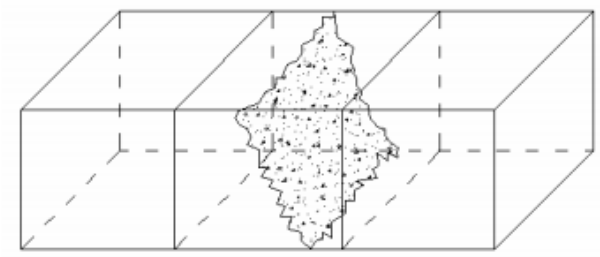

Gambar 2. Patah Pada 1/3 Bentang Tengah (Sumber: SNI-4431-2011)

2. Untuk pengujian dengan keadaan patahnya benda uji ada di luar pusat (daerah 1/3 jarak titik perletakan bagian tengah), dan jarak antara titik pusat dan titik patah kurang dari 5\% dari jarak antara titik perletakan makan kuat lentur beton dihitung menurut persamaan sebagai berikut.

$$
\sigma=\frac{P \times a}{b \times h^{2}}
$$

Keterangan:

$\sigma \quad$ adalah kuat lentur benda uji (MPa)

$\mathrm{P}$ adalah beban tertinggi yang terbaca pada mesin uji (ton)

L adalah jarak (bentang) antara dua garis perletakan $(\mathrm{mm})$

b adalah lebar tampang lintang patah arah horisontal (mm)

h adalah lebar tampang lintang patah arah vertikal (mm) 
Ilustrasi mengenai gambar patah pada daerah di luar pusat atau lebih dari 1/3 jarak titik perletakan bagian tengah dapat dilihat pada Gambar 3.

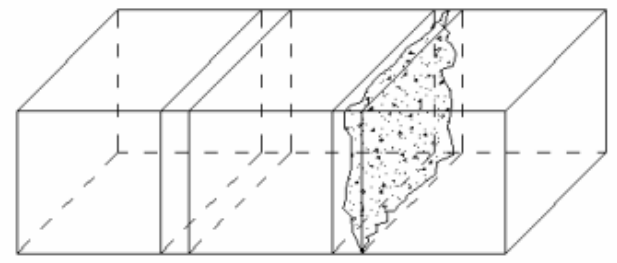

Gambar 3. Patah Di Luar 1/3 Bentang Tengah dan Garis Patah Pada <5\% Dari Bentang (Sumber: SNI-4431-2011)

\subsection{Struktur Beton Komposit}

Struktur komposit adalah struktur yang terdiri dari dua material atau lebih dengan sifat bahan yang berbeda dan membentuk satu kesatuan sehingga menghasilkan sifat gabungan yang lebih baik dengan memanfaatkan karakteristik masing-masing bahan secara optimal (Evendy et al, 2013). Beton komposit adalah elemen beton pracetak, beton cor di tempat, atau keduanya, yang dibangun dalam pengecoran yang terpisah tetapi saling berhubungan sedemikian sehingga semua elemen merespon terhadap beban sebagai sebuah unit (SNI 2847 2013). Contoh beton komposit adalah beton dengan baja, kayu dengan beton, dan beton prategang yang terdiri dari beton biasa dan kabel prategang.

Ditinjau dari momen inersia, balok komposit mempunyai momen inersia yang lebih besar dibandingkan dengan dua balok yang disusun tanpa adanya penghubung geser. Hal tersebut terjadi dikarenakan pada balok komposit, kedua balok dianggap satu kesatuan yang sudah dihubungkan dengan penghubung geser. Gambar 4 dan Gambar 5 merupakan momen inersia yang terjadi pada balok yang diberi penghubung geser dan balok yang tidak digabungkan dengan penghubung geser.

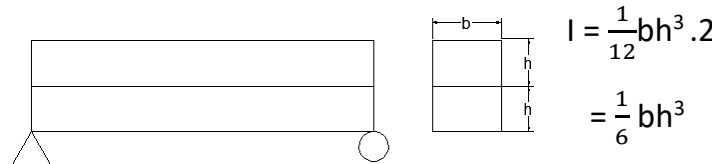

Gambar 4. Momen Inersia Penampang 2 Balok Biasa Ditumpuk
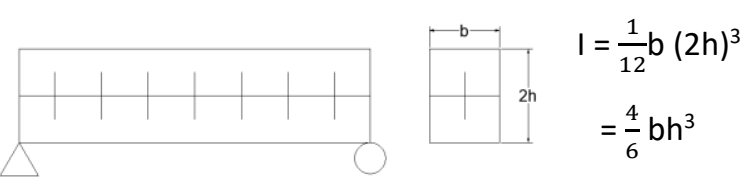

Gambar 5. Momen Inersia Penampang 2 Balok Yang Dikomposit

\subsection{Struktur Beton Monolit}

Beton monolit adalah beton yang memiliki sifat satu kesatuan. Sifat kesatuan ini didapatkan saat pengecoran beton yang dilakukan secara bersamaan, sehingga beton menyatu satu sama lain. Dengan kata lain beton monolit adalah beton yang dicor secara bersamaan. Contoh pengecoran beton monolit yaitu pengecoran pada balok dan pelat lantai.

\subsection{Penghubung Geser}

Struktur komposit memerlukan penghubung geser yang berfungsi untuk pentransferan gaya geser ke struktur dan juga sebagai penghubung antara berbagai jenis material beton komposit supaya tidak terjadi pemisahan antar material pada saat diberikan beban. Penghubung geser mengakibatkan beton komposit dapat bekerja sama satu dengan lainnya. Hal ini akan mengakibatkan kekompakan struktur yang didukung juga dengan kekuatan dari penghubung geser yang terpasang.

Berdasarkan SNI 1729-2002 (2002) seluruh gaya geser horizontal pada bidang kontak beton dengan baja harus disalurkan menggunakan penghubung geser. Penggunaan untuk aksi komposit di mana beton mengalami gaya tekan akibat lentur, gaya geser horizontal total yang bekerja pada daerah yang dibatasi oleh titik-titik momen positif maksimum dan 
momen nol yang berdekatan, harus diambil sebagai nilai terkecil diantara $\mathrm{A}_{\mathrm{s}} \cdot \mathrm{f}_{\mathrm{y}}, 0,85 \cdot \mathrm{f}_{\mathrm{c}}{ }^{\prime} \cdot \mathrm{A}_{\mathrm{c}}$ atau $\Sigma \mathrm{Q}_{\mathrm{n}}$. Jika besarnya gaya geser horizontal $\left(\mathrm{V}_{\mathrm{h}}\right)$ ditentukan oleh $\mathrm{A}_{\mathrm{s}} . \mathrm{f}_{\mathrm{y}}$ atau $0,85 . \mathrm{f}_{\mathrm{c}}{ }^{\prime} . \mathrm{A}_{\mathrm{c}}$, maka yang terjadi adalah perilaku aksi komposit penuh, dan jumlah penghubung geser yang diperlukan adalah:

$$
\mathrm{N}_{1}=\frac{V h}{Q n}
$$

Dengan $Q_{n}$ adalah kuat geser nominal satu buah penghubung geser. Jenis penghubung geser yang dipersyaratkan dalam SNI 1729-2002 adalah berupa paku berkepala (stud) dengan panjang dalam kondisi terpasang tidak kurang dari empat kali diameternya. Kuat nominal penghubung geser jenis paku yang ditanam di dalam pelat beton masif yaitu:

$$
\mathrm{Q}_{\mathrm{n}}=0,5 \cdot \mathrm{A}_{\mathrm{sc}} \sqrt{f c^{\prime} . E c} \leq \mathrm{A}_{\mathrm{sc}} \cdot \mathrm{f}_{\mathrm{u}} \ldots \ldots
$$

\section{Keterangan:}

$\mathrm{A}_{\mathrm{sc}}$ adalah luas penampang penghubung geser jenis paku $\left(\mathrm{mm}^{2}\right)$

$f_{u}$ adalah tegangan putus penghubung geser jenis paku (Mpa)

$Q_{n}$ adalah kuat geser nominal untuk penghubung geser $(\mathrm{N})$

\subsection{Pola Retak}

Retak merupakan jenis kerusakan yang sering terjadi pada struktur beton, yang secara visual nampak sperti garis. Pada struktur beton retak terjadi pada saat beton sebelum mengeras maupun setelah beton mengeras. Retak pada beton yang mulai mengeras terjadi saat beton sudah dibebani, beton yang mengeras pada musim dingin, susut (shrinkage), penurunan (setlement) dan penurunan acuan (formwork).

Terdapat banyak jenis pola retak yang terjadi pada beton. Pola retak dapat dibedakan antara lain sebagai berikut:
1. Retak lentur (flexural crack), retak yang terjadi pada daerah yang momen lentur lebih besar dan gaya geser kecil. Untuk arah retaknya terjadi hampir tegak lurus pada sumbu balok. Gambar 6 merupakan contoh gambar retak lentur.

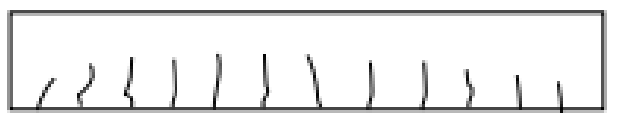

Gambar 6. Retak Lentur (Flexural Crack)

2. Retak geser pada bagian balok (web shear crack), merupakan keretakan miring yang terjadi pada daerah garis netral penampang dimana gaya geser maksimum dan tegangan aksial sangat kecil. Untuk gambar web shear crack dapat dilihat pada Gambar 7.

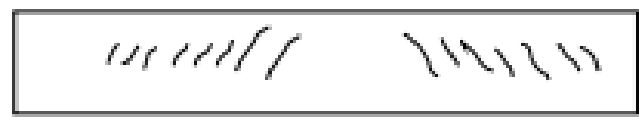

Gambar 7. Retak Geser Pada Bagian Balok (Web Shear Crack)

3. Retak geser-lentur (flexural shear crack), merupakan perambatan retak miring dari retak lentur yang sudah terjadi sebelumnya. Gambar dari retak geser-lentur dapat dilihat pada Gambar 8.

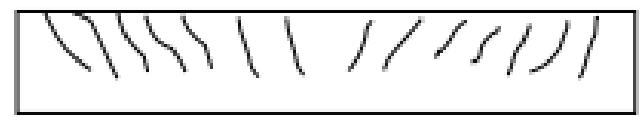

Gambar 8. Retak Geser Geser-Lentur (Flexural Shear Crack)

4. Retak puntir (torsion crack). Retak ini mirip retak geser terkecuali retak puntir melingkar di sekeliling balok. Contoh jika sebuah balok tanpa tulangan menerima torsi murni, maka beton tersebut akan retak dan runtuh pada disepanjang garis spiral $45^{\circ}$ karena tarik diagional disebabkan tegangan puntir. Gambar 9 merupakan gambar retak puntir. 


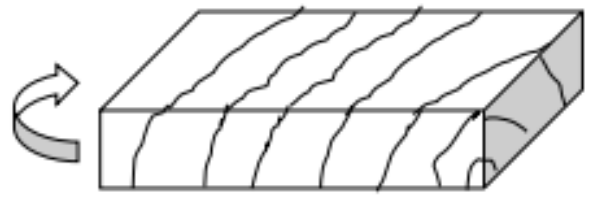

Gambar 9. Retak Puntir (Torsion Crack)

5. Retak lekatan adalah retak yang terjadi di sekitar tulangan. Hal ini terjadi akibat kemampuan awal tulangan melawan beton, terjadi displacement pada tulangan di dalam beton dimana terjadi interlocking dan menghasilkan retak radial, tegangan lekat dan kekakuan beton ditahan oleh ulir tulangan di sepanjang penyaluran gaya di dalam beton. Gambar retak lekatan dapat dilihat pada Gambar 10.

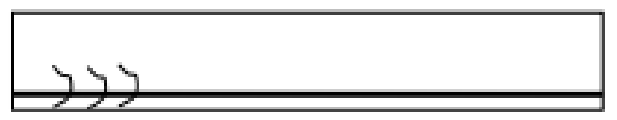

Gambar 10. Retak Lekatan

\section{METODE PENELITIAN}

Terdapat tiga tahapan yang digunakan pada penelitian ini. Berikut merupakan bagan alir untuk memperjelas tahapan penelitian yang dapat dilihat pada Gambar 11.

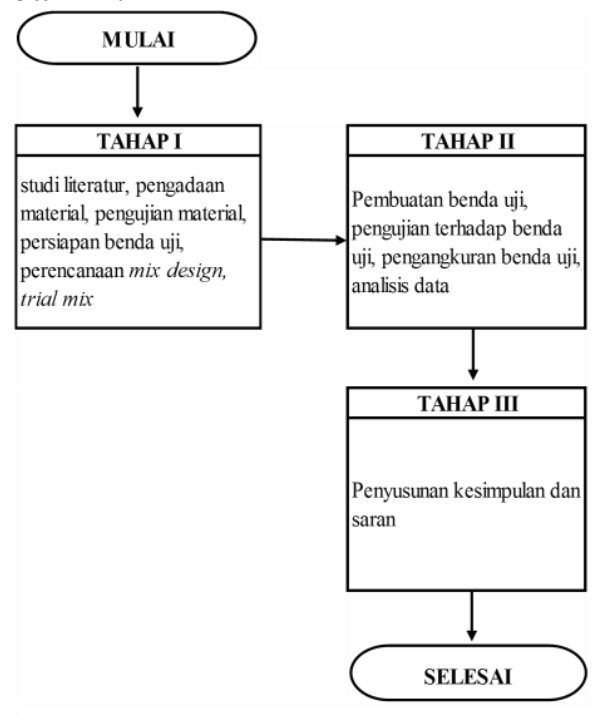

Gambar 11. Bagan Alir Tahapan Penelitian

\section{ANALISIS \\ DATA \\ DAN}

\section{PEMBAHASAN}

\subsection{Berat Massa Volume Beton Benda Uji Silinder}

Berat massa volume beton merupakan perbandingan antara berat benda uji beton yang ditimbang saat beton berumur 28 hari dengan volume benda uji. Hasil perhitungan berat massa volume beton benda uji silinder adalah sebagai berikut:

1. Berat benda uji silinder kode $1=$ $12,49 \mathrm{~kg}$

2. Perhitungan volume benda uji silinder

$$
\begin{aligned}
& =\pi \times r^{2} \times t \\
& =\pi \times 0,075^{2} \times 0,3 \\
& =0,00529 \mathrm{~m}^{3}
\end{aligned}
$$

3. Perhtiungan berat massa volume beton

$$
\begin{aligned}
& =\frac{\text { berat benda uji silinder }}{\text { volume benda uji silinder }} \\
& =\frac{12,49}{0,00529} \\
& =2357,159 \mathrm{~kg} / \mathrm{m}^{3}
\end{aligned}
$$

Berdasarkan perhitungan tersebut,

\begin{tabular}{|c|c|c|c|c|}
\hline $\begin{array}{c}\text { Kode } \\
\text { Benda } \\
\text { Uji }\end{array}$ & $\begin{array}{c}\text { Berat } \\
\text { Benda } \\
\text { Uji }(\mathrm{kg})\end{array}$ & $\begin{array}{l}\text { Volume } \\
\text { Benda } \\
\text { Uji }\left(\mathrm{m}^{2}\right)\end{array}$ & $\begin{array}{c}\text { Berat Massa } \\
\text { Volume Beton } \\
\qquad\left(\mathrm{kg} / \mathrm{m}^{2}\right)\end{array}$ & $\begin{array}{c}\text { Berat Massa } \\
\text { Volume Beton } \\
\text { Rata-Rata } \\
\left(\mathrm{kg} / \mathrm{m}^{2}\right)\end{array}$ \\
\hline 1 & 12,49 & 0,0053 & 2357,159707 & \multirow{6}{*}{2399,308013} \\
\hline 2 & 12,56 & 0,0053 & 2370,37037 & \\
\hline 3 & 12,88 & 0,0053 & 2430,761972 & \\
\hline 4 & 12,47 & 0,0053 & 2353,385232 & \\
\hline 5 & 13,02 & 0,0053 & 2457,183298 & \\
\hline 6 & 12,86 & 0,0053 & 2426,987497 & \\
\hline
\end{tabular}
didapatkan berat massa volume beton benda uji 1 sampai dengan 5 yang dapat dilihat pada Tabel 1 .

Tabel 1. Berat Massa Volume Beton

Berdasarkan Tabel 1. Berat massa volume beton rata-rata sebesar 2399,31 $\mathrm{kg} / \mathrm{m}^{3}$ dan dapat disimpulkan jenis beton dalam penelitian ini adalah beton normal karena berat massa volume beton tersebut berada pada interval $2200 \mathrm{~kg} / \mathrm{m}^{3}-2500$ $\mathrm{kg} / \mathrm{m}^{3}$. 


\subsection{Hasil Pengujian Kuat Tekan}

Dari hasil pengujian kuat tekan yang dilakukan dengan alat Universal Testing Machine didapatkan beban maksimum yaitu pada saat benda uji mengalami keruntuhan akibat menerima pembebanan $\left(\mathrm{P}_{\max }\right)$. Berikut merupakan tahap perhitungan hasil pengujian kuat tekan.

1. Perhitungan luas penampang benda uji silinder (A)

$$
\begin{aligned}
\mathrm{A} & =0,25 \times \pi \times \mathrm{D}^{2} \\
& =0,25 \times \pi \times 150^{2} \\
& =17671,46 \mathrm{~mm}^{2} \\
& =176,7146 \mathrm{~cm}^{2}
\end{aligned}
$$

Dengan pengertian :

A = luas penampang benda uji $\left(\mathrm{cm}^{2}\right)$

$\pi=$ konstanta $(3,1416)$

$\mathrm{D}=$ diameter benda uji silinder $(\mathrm{mm})$

2. Perhitungan kuat tekan benda uji silinder

$=\frac{\text { gaya tekan maksimum }(\mathrm{kN}) \times 100}{\mathrm{~A}}$

$=\frac{450 \times 100}{176,71}$

$=254,65 \mathrm{~kg} / \mathrm{cm}^{2}$

Dengan pengertian 100 merupakan faktor pengkonversi dari $\mathrm{kN} \mathrm{ke} \mathrm{kg}$.

3. Pengkonversian kuat tekan benda uji silinder ke benda uji kubus

$$
\begin{aligned}
& =\frac{\text { kuat tekan benda uji silinder }}{0,83} \\
& =\frac{254,65}{0,83} \\
& =306,81 \mathrm{~kg} / \mathrm{cm}^{2}
\end{aligned}
$$

Dengan pengertian 0,83

merupakan faktor pengkonversi dari silinder ke kubus.

Dari perhitungan tersebut, dapat ditentukan kekuatan kuat tekan dari enam sampel benda uji silinder yang dapat di lihat pada Gambar 12.
Kuat Tekan Umur 28 hari

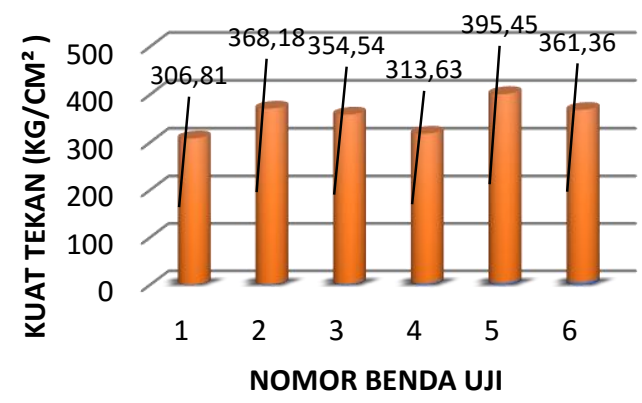

\section{Gambar 12. Grafik Kuat Tekan Beton Umur 28 Hari}

Dapat dilihat pada Gambar 12, hasil dari masing-masing benda uji telah mencapai kuat tekan yang telah ditentukan yaitu K-300. Pada Gambar 12 dapat diketahui kuat tekan beton umur 28 hari tertinggi mencapai $395,45 \mathrm{~kg} / \mathrm{cm}^{2}$ dan yang terendah mencapai $306,81 \mathrm{~kg} / \mathrm{cm}^{2}$. Rata- rata kuat tekan benda uji silinder pada penelitian ini adalah $349 \mathrm{~kg} / \mathrm{cm}^{2}$.

\subsection{Hasil Pengujian Kuat Lentur Balok Beton $15 \mathrm{~cm} \times 15 \mathrm{~cm} \times 60 \mathrm{~cm}$}

Dari hasil pengujian kuat tekan yang dilakukan didapatkan beban lentur maksimum yaitu pada saat benda uji mengalami keruntuhan akibat menerima pembebanan $\left(\mathrm{P}_{\max }\right)$. Berikut merupakan tahap perhitungan hasil pengujian kuat lentur.

1. Mengkonversi gaya tekan yang didapat dari $\mathrm{KN}$ ke $\mathrm{kg}(1 \mathrm{KN}=100 \mathrm{~kg})$.

2. Mencari nilai kuat lentur (Modulus of Rupture).

Diketahui:

Beban lentur $(\mathrm{P})=43,20 \mathrm{KN}=4320 \mathrm{~kg}$ Panjang bentang antar 2 tumpuan $(\mathrm{L})=$ $45 \mathrm{~cm}$

$$
\begin{aligned}
& \text { Lebar balok }(\mathrm{b})=15 \mathrm{~cm} \\
& \text { Tinggi balok }(\mathrm{h})=15 \mathrm{~cm} \\
& \begin{aligned}
\text { Modulus of Rupture }(\boldsymbol{\sigma M R}) \\
=(\mathrm{P} \times \mathrm{L}) /\left(\mathrm{b} \times \mathrm{h}^{2}\right) \\
=(4320 \times 45) /\left(15 \times 15^{2}\right) \\
=57,60 \mathrm{~kg} / \mathrm{cm}^{2}
\end{aligned}
\end{aligned}
$$


Dari contoh perhitungan tersebut, dapat ditentukan kuat lentur dari 6 sampel benda uji balok beton lama dan baru berukuran $15 \mathrm{~cm} \times 15 \mathrm{~cm} \times 60 \mathrm{~cm}$ yang dapat dilihat pada Gambar 13.

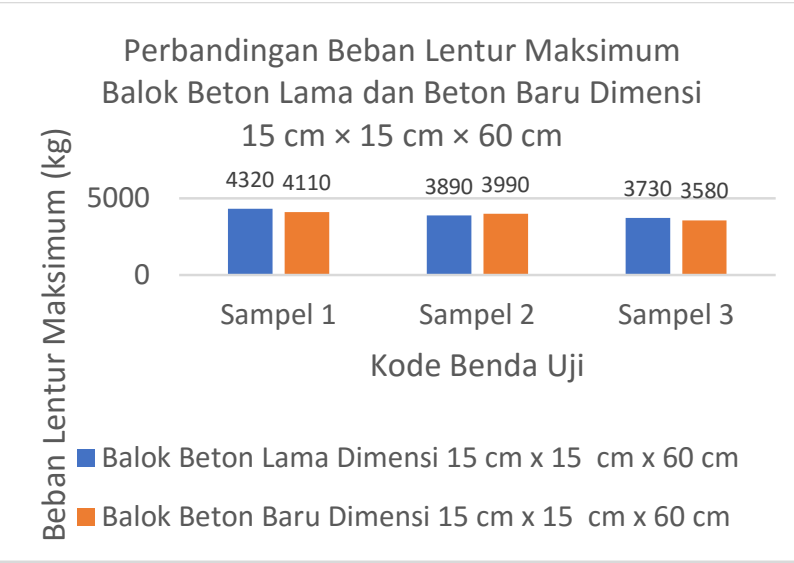

Gambar 13. Grafik Perbandingan Beban Lentur Maksimum Balok Beton Lama dan Beton Baru Dimensi $15 \mathrm{~cm} \times 15 \mathrm{~cm}$ $\times 60 \mathrm{~cm}$

Berdasarkan Gambar 13 hasil pengujian beban lentur maksimum balok lama yang terbesar yaitu $4320 \mathrm{~kg}$, sedangkan beban lentur maksimum terkecil dari hasil pengujian yaitu $3730 \mathrm{~kg}$. Dilihat dari hasil pengujian nilai kapasitas beban maksimum tidak terlihat jauh berbeda antara sampel 1,2, dan 3. Untuk nilai rata-rata beban lentur maksimum balok beton lama ukuran $15 \mathrm{~cm} \times 15 \mathrm{~cm} \times$ $60 \mathrm{~cm}$ adalah sebagai berikut:

$$
\begin{aligned}
\text { Rata-Rata Beban Lentur } \\
=\frac{\mathrm{P} 1+\mathrm{P} 2+\mathrm{P} 3}{3} \\
=\frac{4320+3890+3730}{3} \\
=3980 \mathrm{~kg}
\end{aligned}
$$

Dari perhitungan rata-rata beban lentur balok beton lama ukuran $15 \mathrm{~cm} \times$ $15 \mathrm{~cm} \times 60 \mathrm{~cm}$ didapatkan nilai $3980 \mathrm{~kg}$. Perhitungan nilai rata-rata kuat lentur balok beton lama berukuran $15 \mathrm{~cm} \times 15$ $\mathrm{cm} \times 60 \mathrm{~cm}$ berdasarkan hasil pengujian Gambar 13 yaitu:
Rata-Rata Kuat Lentur

$$
\begin{aligned}
& =\frac{\sigma M R 1+\sigma M R 2+\sigma M R 3}{3} \\
& =\frac{57,60+51,87+49,73}{3} \\
& =53,06 \mathrm{~kg} / \mathrm{cm}^{2}
\end{aligned}
$$

Rata-rata kuat lentur balok beton lama berukuran $15 \mathrm{~cm} \times 15 \mathrm{~cm} \times 60 \mathrm{~cm}$ yaitu sebesar $53,06 \mathrm{~kg} / \mathrm{cm}^{2}$.

Dari Gambar 13 dapat dilihat bahwa nilai beban lentur terbesar adalah $4110 \mathrm{~kg}$ dan beban lentur terkecil adalah $3580 \mathrm{~kg}$. Beban lentur maksimum yang dihasilkan didapatkan nilai yang tidak jauh berbeda dari sampel 1,2, dan 3 dari balok beton baru ukuran $15 \mathrm{~cm} \times 15 \mathrm{~cm} \times$ $60 \mathrm{~cm}$. Nilai rata-rata beban lentur balok beton baru ukuran $15 \mathrm{~cm} \times 15 \mathrm{~cm} \times 60 \mathrm{~cm}$ adalah sebagai berikut:

Rata-Rata Beban Lentur

$$
\begin{aligned}
& =\frac{\mathrm{P} 1+\mathrm{P} 2+\mathrm{P} 3}{3} \\
& =\frac{3580+3990+4110}{3} \\
& =3893,33 \mathrm{~kg}
\end{aligned}
$$

Rata-rata beban lentur balok beton baru ukuran $15 \mathrm{~cm} \times 15 \mathrm{~cm} \times 60 \mathrm{~cm}$ adalah $3893,33 \mathrm{~kg}$.

Perhitungan nilai rata-rata kuat lentur balok beton baru berukuran $15 \mathrm{~cm}$ $\times 15 \mathrm{~cm} \times 60 \mathrm{~cm}$ berdasarkan hasil pengujian Tabel 4.15 yaitu:

$$
\begin{aligned}
\text { Rata-Rata Kuat Lentur } \\
\\
=\frac{\sigma \mathrm{MR} 1+\sigma \mathrm{MR} 2+\sigma \mathrm{MR} 3}{3} \\
=\frac{47,73+53,20+54,80}{3} \\
=51,91 \mathrm{~kg} / \mathrm{cm}^{2}
\end{aligned}
$$

Rata-rata kuat lentur balok beton baru berukuran $15 \mathrm{~cm} \times 15 \mathrm{~cm} \times 60 \mathrm{~cm}$ yaitu sebesar $51,91 \mathrm{~kg} / \mathrm{cm}^{2}$.

\subsection{Hasil Pengujian Kuat Lentur Balok Beton Monolit dan Komposit $15 \mathrm{~cm} \times$ $30 \mathrm{~cm} \times 60 \mathrm{~cm}$}

Dari hasil pengujian kuat tekan yang dilakukan didapatkan beban lentur maksimum yaitu pada saat benda uji mengalami keruntuhan akibat menerima pembebanan $\left(\mathrm{P}_{\max }\right)$. Berikut merupakan 
tahap perhitungan hasil pengujian kuat lentur.

1. Mengkonversi gaya tekan yang didapat dari $\mathrm{KN}$ ke $\mathrm{kg}(1 \mathrm{KN}=100 \mathrm{~kg})$.

2. Mencari nilai kuat lentur (Modulus of Rupture).

Diketahui:

Beban lentur $(\mathrm{P})=146 \mathrm{KN}=14600 \mathrm{~kg}$ $45 \mathrm{~cm}$

Panjang bentang antar 2 tumpuan $(\mathrm{L})=$

Lebar balok $(b)=15 \mathrm{~cm}$

Tinggi balok $(\mathrm{h})=30 \mathrm{~cm}$

Modulus of Rupture (6MR)

$$
\begin{aligned}
& =(\mathrm{P} \times \mathrm{L}) /\left(\mathrm{b} \times \mathrm{h}^{2}\right) \\
& =(14600 \times 45) /\left(15 \times 30^{2}\right) \\
& =48,67 \mathrm{~kg} / \mathrm{cm}^{2}
\end{aligned}
$$

Dari contoh perhitungan tersebut, dapat ditentukan kuat lentur dari 3 sampel benda uji balok monolit berukuran $15 \mathrm{~cm}$ $\times 30 \mathrm{~cm} \times 60 \mathrm{~cm}$ yang dapat dilihat pada Gambar 14.

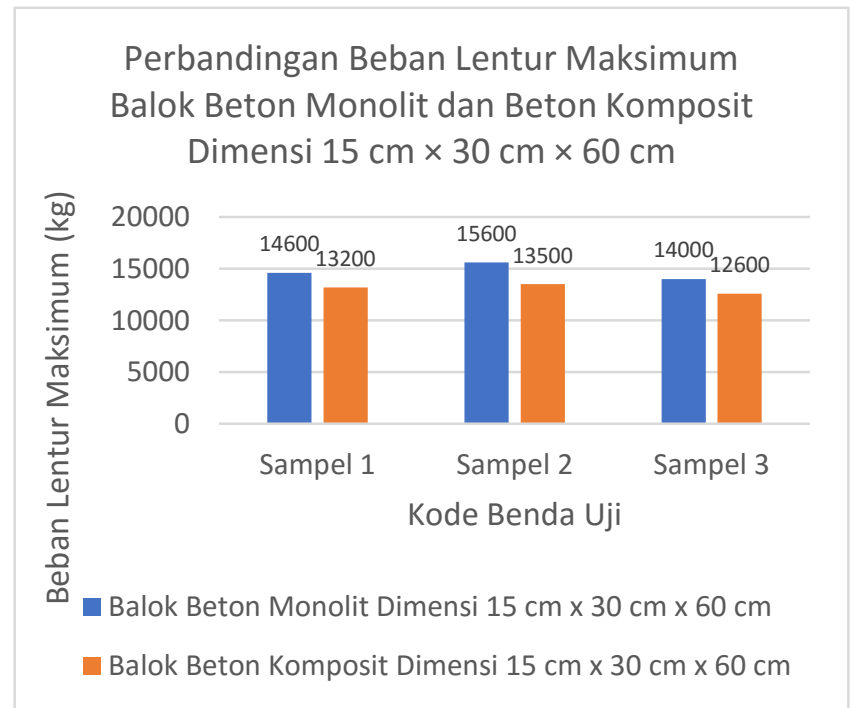

Gambar 14. Grafik Perbandingan Beban Lentur Maksimum Balok Beton Monolit dan Beton Komposit Dimensi $15 \mathrm{~cm} \times 30$ $\mathrm{cm} \times 60 \mathrm{~cm}$

Dari Gambar 14, dapat dilihat bahwa beban lentur maksimum yang dapat dipikul oleh balok beton monolit ukuran $15 \mathrm{~cm} \times 30 \mathrm{~cm} \times 60 \mathrm{~cm}$ lebih besar dibandingkan dengan balok beton berukuran $15 \mathrm{~cm} \times 15 \mathrm{~cm} \times 60 \mathrm{~cm}$. Hal tersebut membuktikan bahwa apabila kita memperbesar dimensi tinggi balok maka kekuatan beban lentur maksimum yang mampu dipikul oleh balok akan meningkat. Rata-rata beban lentur maksimum balok beton monolit ukuran $15 \mathrm{~cm} \times 30 \mathrm{~cm} \times 60 \mathrm{~cm}$ yaitu:

Rata-Rata Beban Lentur

$$
\begin{aligned}
& =\frac{\mathrm{P} 1+\mathrm{P} 2+\mathrm{P} 3}{3} \\
& =\frac{14600+15600+14000}{3^{3}} \\
& =14733,33 \mathrm{~kg}
\end{aligned}
$$

Rata-rata beban lentur maksimum yang didapatkan dari pengujian balok beton monolit ukuran $15 \mathrm{~cm} \times 30 \mathrm{~cm} \times 60$ $\mathrm{cm}$ yaitu sebesar $14733,33 \mathrm{~kg}$.

Perhitungan nilai rata-rata kuat lentur balok beton monolit berukuran 15 $\mathrm{cm} \times \quad 30 \mathrm{~cm} \times 60 \mathrm{~cm}$ berdasarkan hasil pengujian Gambar 14 yaitu:

$$
\begin{aligned}
\text { Rata-Rata Kuat Lentur } \\
=\frac{\sigma M R 1+\sigma M R 2+\sigma M R 3}{3} \\
=\frac{48,67+52,00+46,67}{3} \\
=49,11 \mathrm{~kg} / \mathrm{cm}^{2}
\end{aligned}
$$

Rata-rata kuat lentur balok beton monolit berukuran $15 \mathrm{~cm} \times 30 \mathrm{~cm} \times 60 \mathrm{~cm}$ yaitu sebesar $49,11 \mathrm{~kg} / \mathrm{cm}^{2}$.

Berdasarkan Gambar 14, dapat dilihat bahwa balok komposit berukuran $15 \mathrm{~cm} \times 30 \mathrm{~cm} \times 60 \mathrm{~cm}$ mengalami peningkatan beban lentur maksimum yang dapat dipikul lebih besar dibandingkan dengan balok berukuran $15 \mathrm{~cm} \times 15 \mathrm{~cm} \times$ $60 \mathrm{~cm}$. Akan tetapi dengan dimensi balok yang sama antara balok beton monolit dan komposit mampu memikul beban lentur maksimum yang sama. Nilai rata-rata beban lentur balok beton komposit ukuran $15 \mathrm{~cm} \times 30 \mathrm{~cm} \times 60 \mathrm{~cm}$ anatara lain:

$$
\begin{aligned}
\text { Rata-Rata Beban Lentur } \\
=\frac{\mathrm{P} 1+\mathrm{P} 2+\mathrm{P} 3}{3} \\
=\frac{13500+12600+13200}{3} \\
=13100 \mathrm{~kg}
\end{aligned}
$$

Rata-rata beban lentur yang didapatkan dari hasil pengujian balok 
beton monolit ukuran $15 \mathrm{~cm} \times 30 \mathrm{~cm} \times 60$ cm yaitu $13100 \mathrm{~kg}$.

Perhitungan nilai rata-rata kuat lentur balok beton komposit berukuran 15 $\mathrm{cm} \times 30 \mathrm{~cm} \times 60 \mathrm{~cm}$ berdasarkan hasil pengujian Gambar 14 yaitu:

$$
\begin{aligned}
\text { Rata-Rata Kuat Lentur } \\
=\frac{\sigma \mathrm{MR} 1+\sigma \mathrm{MR} 2+\sigma \mathrm{MR} 3}{3} \\
=\frac{45,00+42,00+44,00}{3} \\
=43,67 \mathrm{~kg} / \mathrm{cm}^{2}
\end{aligned}
$$

Rata-rata kuat lentur balok beton komposit berukuran $15 \mathrm{~cm} \times 30 \mathrm{~cm} \times 60$ $\mathrm{cm}$ yaitu sebesar $43,67 \mathrm{~kg} / \mathrm{cm}^{2}$. Balok beton monolit berukuran $15 \mathrm{~cm} \times 30 \mathrm{~cm} \times$ $60 \mathrm{~cm}$ dan balok beton komposit berukuran $15 \mathrm{~cm} \times 30 \mathrm{~cm} \times 60 \mathrm{~cm}$ mempunyai rata-rata nilai kuat lentur yang tidak jauh berbeda.

Dari Gambar 14 akan didapatkan hasil persentase kelemahan beban lentur maksimum balok beton komposit terhadap balok beton monolit yang dapat diuraiakan sebagai berikut. Contoh perhitungan menggunakan benda uji sampel 1.

\section{$\%$ Kelemahan $=$}

BebanLentur BetonMonolit-BebanLenturBetonKomposit $\times$ BebanLenturBetonMonolit $100 \%$

$$
\begin{aligned}
= & \frac{14600-13200}{14600} \times 100 \% \\
& =9,59 \% \\
\text { Nilai } \quad & \text { rata-rata persentase }
\end{aligned}
$$

kelemahan beton komposit terhadap beton monolit antara sampel 1, 2, dan 3 dirincikan sebagai berikut.

Rata-Rata Kelemahan

$$
\begin{aligned}
& =\frac{\text { Sampel } 1+\text { Sampel } 2+\text { Sampel } 3}{3} \\
& =\frac{9,59+13,46+10,00}{3} \\
& =11,02 \%
\end{aligned}
$$

Berdasarkan hasil nilai rata-rata persen balok komposit pada Tabel 4.18 dapat ditarik kesimpulan bahwa nilai beban lentur maksimun balok beton komposit menurun sebesar 11,02\% dibandingkan dengan balok beton monolit dengan dimensi yang sama yaitu $15 \mathrm{~cm} \times$ $30 \mathrm{~cm} \times 60 \mathrm{~cm}$.

\subsection{Pola Retak Pada Balok Beton berukuran $15 \mathrm{~cm} \times 30 \mathrm{~cm} \times 60 \mathrm{~cm}$}

Pada pengujian kuat lentur balok beton, hasil yang diperoleh selain beban maksimal didapatkan juga pola retak yang terjadi pada tiap benda uji. Berdasarkan hasil pengujian, pola retak hampir seragam terjadi pada bagian tengah bentang, sehingga dapat dikatakan pola retak yang terjadi merupakan retak lentur. Gambar 15 menunjukkan pola retak yang terjadi pada saat balok komposit berukuran $15 \mathrm{~cm} \times 30 \mathrm{~cm} \times 60 \mathrm{~cm}$ dibebani beban aksial.

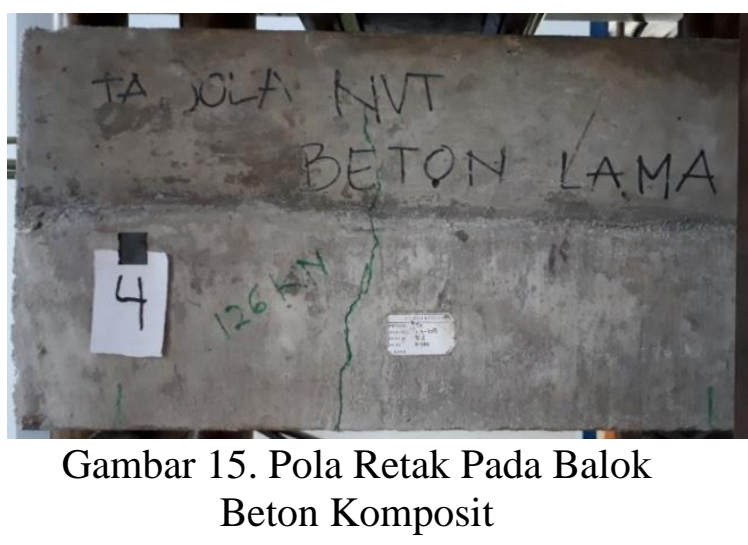

Berdasarkan pengamatan saat pengujian, pola retak dimulai dari bagian bawah balok pada daerah tarik. Peningkatan beban aksial yang terjadi saat pembebanan mengakibatkan retakan yang terjadi semakin panjang. Penambahan panjang retakan tersebut terjadi sepanjang badan balok beton. Retakan yang terjadi merupakan retak lentur, hal ini dikarenakan arah pola retak tegak lurus dengan sumbu balok dan terjadi pada tengah bentang. Akibat beban yang bekerja di atas balok semakin besar, tegangan tarik pada beton melampaui kekuatan tarik beton sehingga menimbulkan retakan pada bagian tarik dan retakan tersebut menyebar ke atas di dalam badan benda uji beton. Retak lentur 
juga terjadi diakibatkan adanya penghubung geser sehingga menahan geser dan mengurangi retak pada $1 / 3$ bentang.

Berdasarkan pengamatan pola retak yang terjadi pada balok beton monolit dengan dimensi $15 \mathrm{~cm} \times 30 \mathrm{~cm} \times$ $60 \mathrm{~cm}$, dapat dikatakan pola retak memiliki hasil yang sama dengan pola retak balok beton komposit. Pada benda uji monolit, retak pertama pada benda uji balok memiliki arah keretakan yang tegak lurus dengan sumbu balok. Pola retak terjadi pada daerah tengah bentang. Keretakan dimulai dari bawah balok lalu bertambah panjang ke arah badan balok. Keretakan baru tidak terjadi sepanjang badan balok. Gambar 16 menunjukkan pola retak yang terjadi pada balok beton monolit dengan dimensi $15 \mathrm{~cm} \times 30 \mathrm{~cm} \times$ $60 \mathrm{~cm}$.

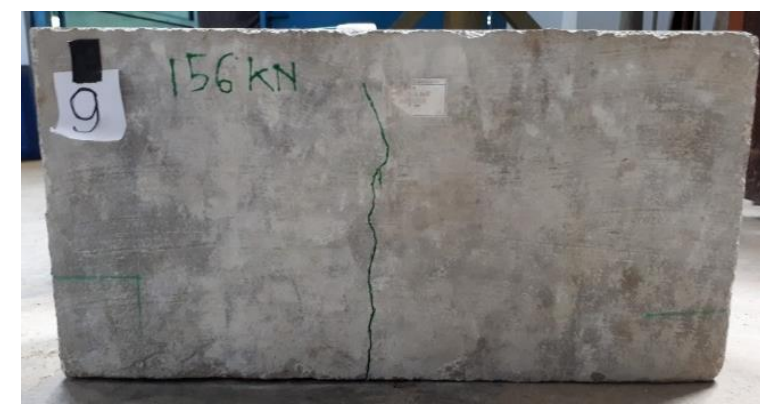

Gambar 16. Pola Retak Pada Balok Beton Monolit

\section{PENUTUP}

\subsection{Kesimpulan}

Berdasarkan dari hasil penelitian yang sudah dilakukan, dapat ditarik kesimpulan antara lain sebagai berikut:

1. Kuat tekan yang direncanakan sebesar K-300 didapatkan hasil kuat tekan ratarata sebesar $349 \mathrm{~kg} / \mathrm{cm}^{2}$.

2. Beban lentur maksimum benda uji balok beton lama berukuran $15 \mathrm{~cm} \times 15$ $\mathrm{cm} \times 60 \mathrm{~cm}$ terbesar yaitu $4820 \mathrm{~kg}$. Untuk beban lentur maksimum benda uji balok beton baru berukuran $15 \mathrm{~cm} \times$ $15 \mathrm{~cm} \times 60 \mathrm{~cm}$ terbesar yaitu $4110 \mathrm{~kg}$.
3. Nilai rata-rata kuat lentur balok beton lama berukuran $15 \mathrm{~cm} \times 15 \mathrm{~cm} \times 60 \mathrm{~cm}$ adalah $53,06 \mathrm{~kg} / \mathrm{cm}^{2}$. Untuk nilai ratarata kuat lentur balok beton baru berukuran $15 \mathrm{~cm} \times 15 \mathrm{~cm} \times 60 \mathrm{~cm}$ adalah $51,91 \mathrm{~kg} / \mathrm{cm}^{2}$

4. Beban lentur maksimum benda uji balok beton monolit berukuran $15 \mathrm{~cm}$ $\times \quad 30 \mathrm{~cm} \times 60 \mathrm{~cm}$ terbesar yaitu $14733,33 \mathrm{~kg}$. Untuk nilai kuat lentur rata-rata adalah sebesar $49,11 \mathrm{~kg} / \mathrm{cm}^{2}$.

5. Beban lentur maksimum benda uji balok beton komposit berukuran $15 \mathrm{~cm}$ $\times 30 \mathrm{~cm} \times 60 \mathrm{~cm}$ terbesar yaitu 13100 $\mathrm{kg}$. Untuk nilai kuat lentur rata-rata adalah sebesar $43,67 \mathrm{~kg} / \mathrm{cm}^{2}$.

6. Beban lentur maksimum antara balok beton monolit berukuran $15 \mathrm{~cm} \times \quad 30$ $\mathrm{cm} \times 60$ cmyang mempunyai rata-rata sebesar 14733,33 kg dibandingkan dengan balok beton komposit berukuran $15 \mathrm{~cm} \times 30 \mathrm{~cm} \times 60 \mathrm{~cm}$ yang mempunyai rata-rata sebesar $13100 \mathrm{~kg}$, didapatkan hasil rata-rata beban lentur maksimum yang hampir sama. Hal tersebut membuktikan bahwa shear connector yang dipasang pada balok beton komposit berukuran $15 \mathrm{~cm} \times 30$ $\mathrm{cm} \times 60 \mathrm{~cm}$ berfungsi dengan baik.

7. Retakan yang terjadi pada benda uji merupakan retak lentur, hal ini dikarenakan arah pola retak tegak lurus dengan sumbu balok dan terjadi pada tengah bentang. Retak lentur juga terjadi diakibatkan adanya penghubung geser sehingga menahan geser dan mengurangi retak pada $1 / 3$ bentang.

8. Berdasarkan pola retak terbukti bahwa shear connector di tengah bentang tidak efektif karena tidak mempengaruhi terjadinya retak.

\subsection{Saran}

Dari kesimpulan yang didapat maka adapun saran dari penulis yaitu antara struktur balok monolit dan komposit yang menghasilkan beban lentur maksimum yang dapat dipikul oleh balok 
beton yang hampir sama. Oleh karena itu untuk metode perbaikan struktur balok lebih baik menggunakan struktur komposit yang masih memanfaatkan fungsi dari beton lama. Pertimbangan penggunaan struktur komposit sendiri adalah lebih efektif dan efisien dari segi biaya yang akan dikeluarkan dan waktu pengerjaan perbaikan struktur balok.

Pada penelitian ini masih perlu adanya beberapa perbaikan. Untuk hasil yang lebih baik adapun saran untuk penelitian selanjutnya yaitu:

1. Dengan menambah ukuran panjang benda uji sepanjang 1,2 meter dengan jarak antar tumpuan $90 \mathrm{~cm}$ sehingga dapat menggunakan alat pengujian yang lebih modern.

2. Diperlukan adanya pemeriksaan regangan dan lendutan pada balok untuk melengkapi informasi tentang kuat lentur balok komposit dengan angkur baja tulangan.

3. Menambah jumlahshearconnectordi daerah dekat tumpuan/ yang terkena gaya shear.

4. Meningkatkan nilai beban lentur balok beton komposit harus lebih dari kapasitas beban maksimum yang mampu dipikul balok beton monolit dengan cara meningkatkan mutu beton pada balok beton baru yang akan dikompositkan.

5. Diperlukan adanya penjelasan lebih detail engenai cara pelaksanaan di lapangan, sehingga saat pekerjaan tidak mengurangi kekuatan sesuai perencanaan.

\section{DAFTAR PUSTAKA}

Antoni dan Nugraha, P. 2007. Teknologi Beton. CV. Andi Offset. Yogyakarta. Evendy, Giri, and Budiwati. 2013.

"Pengujian Kekuatan Penghubung Geser Yang Terbuat Dari Baja Tulangan Berbentuk L Yang
Dibengkokkan Dengan Sudut 45 Derajat”. Jurnal Ilmiah Elektronik Infrastruktur Teknik Sipil. 2.1.

Prayitno, Slamet, Sunarmasto dan Agustya, Hening. 2016. "Pengaruh Panjang Sambungan Lewatan Lebih Dari Syarat SNI-2847-2013 Terhadap Kuat Lentur Pada Balok Beton Bertulang Baja Ulir". E-Jurnal Matriks Teknik Sipil Universitas Sebelas Maret.

Rosmasari, Fery. 2009. "Tinjauan Kuat Lentur Balok Komposit Kayu Beton Dengan Penghubung Geser Paku Polos Dan Paku Ulir". Tugas Akhir. Universitas Muhammadiyah Surakarta.

SNI 03-2847-2002. 2002. Tata Cara Penghitungan Struktur Beton Untuk Bangunan Gedung.

SNI 03-4431-1997. 1997. Metode Pengujian Kuat Lentur Normal Dengan Dua Titik Pembebanan.

SNI 1729-2002. (2002): Tata Cara Perencanaan Struktur Baja untuk Bangunan Gedung. Departemen Perhubungan Umum.

SNI 4431-2011. (2011): Cara Uji Kuat Lentur Beton Normal Dengan Dua Titik Pembebanan. Bandung, Badan Standardisasi Nasional Indonesia.

SNI-1729-2015. 2015. Spesifikasi Untuk Bangunan Baja Struktural. Bandung, Badan Standardisasi Nasional Indonesia.

Tumimomor, M. E. (2016).“Analisis Penghubung Geser (Shear Connector)Pada Balok Baja Dan Pelat Beton".Jurnal Sipil Statik 4 (8) Agustus 2016, 461-470. 